\title{
中国青島における貯水山公園の形成と変容
}

\section{The Formation and Transition of Zhushuishan Park in Qingdao, China}

\author{
江 本硯* 藤川 昌樹** \\ Benyan JIANG Masaki FUJIKAWA
}

\begin{abstract}
This paper aims to analyze how the Zhushuishan Park was formed and transitioned and how the mixed culture of three countries was shown in this park. And what should be emphasized is that it is not only the facilities built on the hill that symbolized the colonial culture, but also the space composition and flora landscape. Generally speaking, the Zhushuishan Park was maintained to be the urban green space through the whole modern period. It was firstly developed as the suburban forest in the German period. A large area of Locust from Berlin and Japanese Black Pine were planted on the hill. However, after that, the Qingdao Shrine was constructed here as the national symbol as soon as Qingdao was occupied by Japan. The Cherry Blossom planted inside the shrine strengthened the Japanese culture. The shrine was preserved by the Japanese government until the year 1945. Therefore, the Qingdao Shrine shaped the characteristic of the hill and left a great effect on its space composition. When the Chinese government received the sovereign of Qingdao and carried out the urban planning, the Hill Zhushuishan was kept to be the urban forest and placed into the urban park system. However, in order to emphasize Chinese culture the Cherry Blossom was replaced by Cedar.
\end{abstract}

Keywords: Zhushuishan Park, urban forest, Qingdao Shrine, transition キーワード：貯水山公園, 都市森林, 青島神社, 変容

\section{1. はじめに}

\section{(1) 背景と研究の目的}

青島は近代植民都市として発展し、数多くの歴史街区、歴史建 築と砲台など戦争の遺物を持つ、中国で有名な「歴史文化名城」 である。近年、青島は歴史文化の保護を重視し、1995-2010 年の 「青島市都市全体計画」の第十一章「歴史文化名城の保護と都市 の風貌」に歴史文化名城の保護を特定項目として計画した。その 中では近代都市文化をテーマとし、都市の空間構成、建築風貌を 保護し、人文景観と遺物を積極的に活用寸ると述べている ${ }^{1)}$ 。

しかし、都市空間や建築が強調されたが、近代歴史の遺物であ る公園緑地はあまり注目されていない。それは公園緑地がそもそ も都市のアクティブな空間ではないためと推測される。実際、近 代における重要な都市空間として、公園緑地は都市計画と関連づ けられ、そこには都市建設の理想像が投影されており、人々の生 活史も見られ、貴重な文化価值をもっていると考えられる。

本論文は貯水山公園 2)を例として取り上げる。貯水山公園は 近代青島の各時代の要請によって、それぞれの役割を果たし、各 時期の文化特徴が顕著に見られるからである。まず歴史背景によ って、ドイツ時期（1898-1913）、第一次日本時期（1913-1922）、 中華民国時期（1922-1938）、第二次日本時期（1938-1945）、第二 次中華民国時期（1945-1949）、中華人民共和国時期（1949-)の六 段階に分け、各段階の都市建設と関連づけながら、異なる文化的 背景により貯水山がいかに取り扱われ、いかなる役割が与えられ、 現在の構成ができてきたのかを明らかにする。それをもとに、各 時期の貯水山公園の施設、空間構成、植物景観が示している文化 的特徵を検討することを目的とする。

\section{(2) 研究方法}

主史料として用いるのは、ドイツ時期の『膠奥発展備忘録』33 (以下、『備忘録』)、日本時期の『青島要覧』）戦後公開され た極秘書類『欧受大日記』5)、中華民国時期の『膠奥志』6)など 都市に関する記録である。まず、これらの史料で都市の拡張のプ
ロセスを把握する。そして、その中に含まれる各時期の都市計画 図、市街地図によって、都市の空間を復原的に読み取る。また、 古写真や当時の雑誌、回想録によって、当時の社会や人々の生活 などのソフト面を理解する。さらに、フィールド・ワークを行い、 貯水山公園の現状を把握する。

\section{(3) 先行研究}

青島における近代建築、特にドイツ時期の建築は中国、ドイ ツ、日本の研究者に多く研究されている 》。近年、青島の都市計 画に関わる研究も徐々に増えてきた $\left.{ }^{8}\right)$ 。それに対して、青島の公 園緑地に関する研究は非常に少ない。わずかに南京林業大学鄭愛 芬の修士論文「青島市公園緑地木質植物の多様性」9)が青島の公 園のサンプルを抽出し、各公園の植物の種類の多様性、分布、樹 種の使用頻度の現状について分析しているが、歴史的原因を論じ ていない。

\section{2. 森林緑地としての役割}

1898 年には「膠奥租借条約」に従って、青島を含む膠州はド イツの租借地になった。その時、青島は漁村であった。ドイツが 青島を占領した後、都市計画プラン「新都市の開発計画図」を公 布した。これは真っ白の土地の上に策定された青島における最初 の都市計画である。建設初期には市街地は地勢と気候の良い小港 と青島湾の間の地域に計画され、港、鉄道と重要な施設の位置が 決められた ${ }^{10)} 1901$ 年に公布された都市計画修正案によると、 建設範囲は変わらずに、都市は青島欧州人区、大鮑島中国人区と 台東・台西の二つ労工区に分けられ、住宅や商労働者が集まる 市が建設されている (図-1)。『備忘録』第六章建築業「大港の 工事」によれば、埠頭区には道路網が形成されたが、施設は主に 倉庫、船の工場などであった。租借地内の海湾、山及び欧州人区 の街路はすべてドイツ語で命名され、中国人区と労工区は中国語 で命名された。

都市建設と平行して、林業を重視するドイツ政府は郊外の景

筑波大学システム情報工学研究科踟波大学システム情報系 
観を向上させ、上水を改善するために 1898 年に青島の丘陵や山 に植林する計画をたてた ${ }^{11}$ 。1900 年にはドイツ総督府は第一期 植林する用地としてイルチス山（現太平山）、ビスマーク山（現青 島山)、モルトケ山 (現貯水山)を購入した ${ }^{12)}$ 。最初、地元の樹木が 少なかったため、緑化用の苗木は主にドイツ、日本、及びそのほ かの東アジアから輸入された ${ }^{13)}$ 。のうちには当時ベルリンの市 樹であったニセアカシアは ${ }^{14)}$ 青島の市街や山で最も多く使われ、 現在でも青島の緑地に多く残っている。ドイツはニセアカシアで 自国の景観の特徵を作り出寸計画意図があったと推測される。注 意すべきは、クロマツと桜は何れも日本の樹種であるが、この時 期に青島に輸入されたものだったことである。

1906 年、軍事上の理由より、ドイツ膠奥地区砲兵管理部門は 小鮑島山間の窪地 (現貯水山の南)に移された ${ }^{15}$ )。これに関しては、 1906-1907 年の『備忘録』第六章建築業の「小鮑島谷地砲兵倉庫 施設」に「小鮑島の谷地にビルが一棟、庫が二ヶ所、銃器工場及 び附属施設が建設された」と記されている ${ }^{16)}$ 。弾薬庫と大港を連 結する鉄道も敷かれていた。建物と鉄道の工事爆破によって生じ た石材は谷のダムと貯水池の建設に使用された ${ }^{15)}$ 。また、周辺に は一年生二セアカシア 26,400 株、二年生クロマツ 78,000 株及び 数万株の広葉樹と桜など多くの種類の日本の観賞樹木が植えられ た ${ }^{15)}$ 。

ドイツ時期にはこのような公園の機能を持っていた緑地が多 く作られたが、公園制度自体が未整備であり、都市計画の中に位 置づけられなかった。

\section{3. 青島神社の形成と景観特徵 \\ (1)青島神社の創建}

日本は 1914 年 11 月に青島を占領した。青島は日本人に開放 されたため、占領直後から青島に住む日本人の数が急激に増加し た。ドイツ時代の人口調査によると、1913 年に青島に在住して いた日本人はわずかに 316 人であり ${ }^{17)}$ 、総人口（60484人)の $0.5 \%$ をしめていたに過ぎない。ところが、1915 年 12 月の調査による と、青島の日本人は 11,009 人に達し ${ }^{18)}$ 、総人口 $(76,588$ 人)の $14.4 \%$ に及んでいた。人口の激増に伴い、都市が拡張する段階 を迎えた。

1915 年には日本はドイツが建設した部分をもとに、青島の拡 大工事計画を編成した。その中に掲載されている「青島市街図」

(図一1)によると、まず、都市の範囲は小港から大港一帯に拡 張していった。そして、市街地における海湾・山・街路等のドイ ツ語の名称はすべて日本語に変えられたことが知られる。しかし、 中国人が建設した大鮑島市街地、台東鎮と台西鎮の名前はそのま ま使われている。

都市を拡大する工事は三期に分けられた ${ }^{19)}$ 。第一期の工事に は埠頭区と大鮑島の間の新市場、若鶴山（現貯水山）西側の市街地、 小港北東側の市街地が指定された。中には主に緊急に必要となる 住宅及び学校、墓地、郵便局などの施設が含まれている。若鶴山 付近の大和町一帯には住宅地、花咲町には第一小学校、若鶴山に は青島神社が計画された。第二期工事は都市が拡張する次の段階 を想定し、主に台東鎮と大港の間及ひ南東部忠ノ海の海岸に設定 された。台東鎮の西北部に工場用地、大港一帯の予定市街が計画 された。第三期工事は主に大港の浅瀬一帯約六十万坪を埋立し、 商業市街とするものであった。こうして、若鶴山の北側に工場、 西側に住宅地、南側に学校、東側に日本人墓地など様々な施設が 集まって (図一2)、人々を引きつけ、山が市街の中心の一つにな っていったと推測される。

前述のように、青島神社は重要な公共施設であり、第一期工 事に含まれていた。1919 年の『神社協会雑誌』「各地通信欄」に は青島神社社務所の通信を掲載しており、青島神社の創立の経緯
が次のように記述されている ${ }^{20)}$

大正三年十一月七日皇軍の青島を占領するや、青島守備軍司 令官神尾大将、浄法寺参謀長、吉村軍政委員長などの間に於 きて当地在住邦人の国家的中心と仰ぐべき一神社創立の議起 り専ら調査準備を急ぎ、将来何時にても直に官弊大社と仰ぎ 得べキ程度の規模となさむとの方針の許に、建築設計は技師 加護谷裕太郎氏主としてそれを担当することとなり、六年一 月末建築設計完成す。

これによれば、日本の「国家的中心」、象徴的な施設として、 青島神社の創立の議が起こり、調査の準備は青島が占領されたの ち早いうちに始まったことが知られる。計画がたてられてから五 年後の 1919 年 11 月には本社青島神社は竣工し、鎮座の祭儀が行

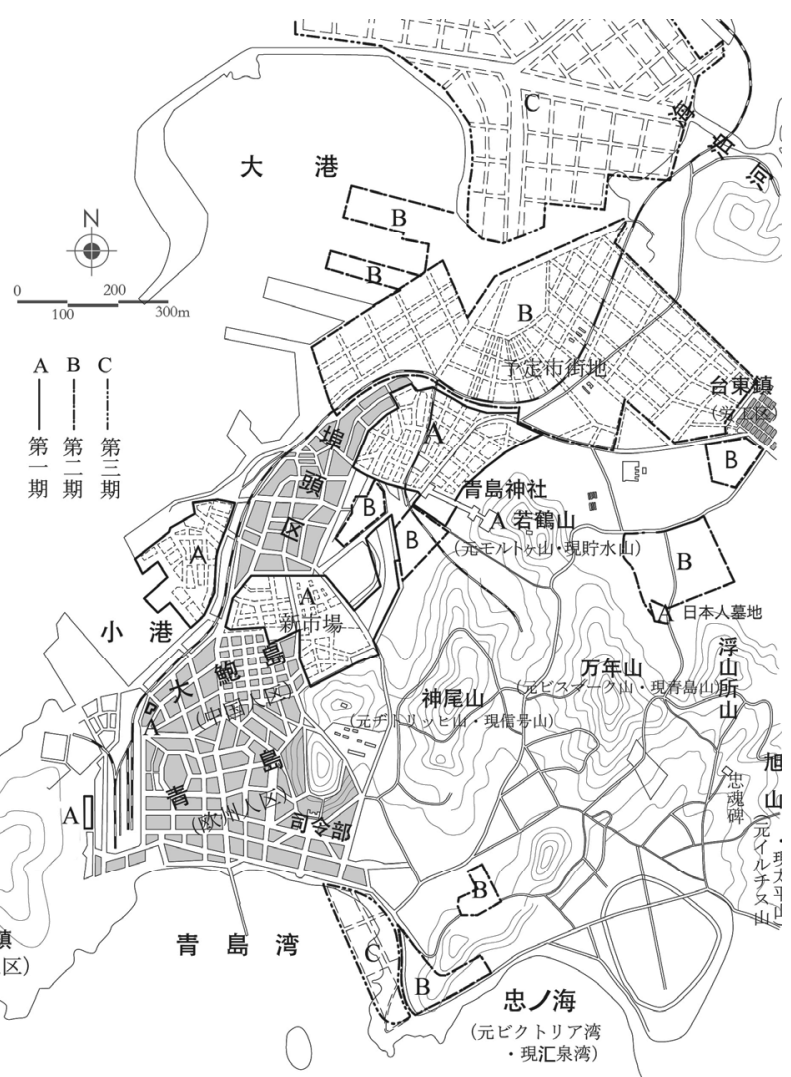

図-1 青島の工事計画 (「青島市街工事計画図」付図「青島市街図」

19) により作成。＊図中の網かけ部分はドイツ時期に建設されたもの)

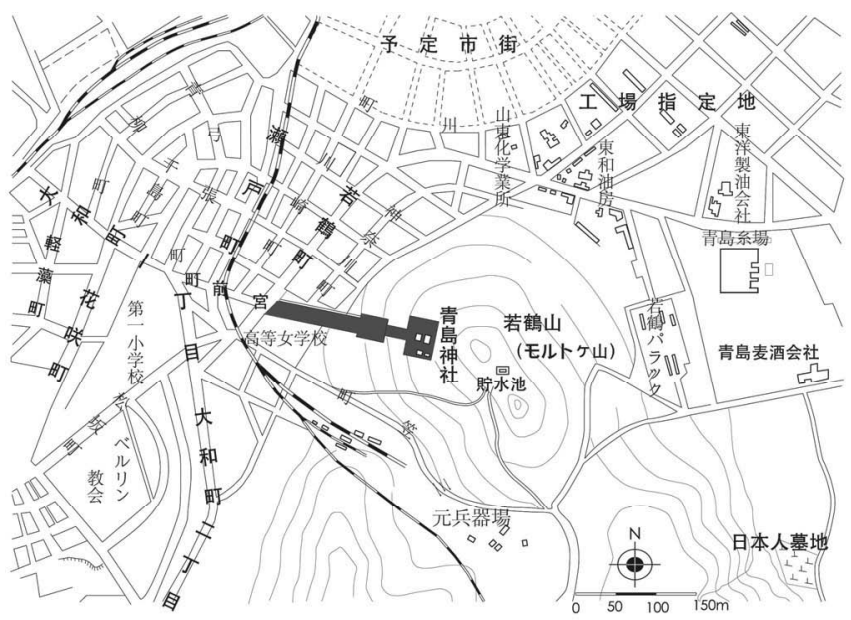

図一2＼cjkstart神社の立地（1919 年の市街地図より作成） 
われた。神社創立事業に関する費用は総て臨時軍政費より支出し、 概略銀十二万圓になったが 20)、その後民営に移された ${ }^{21)}$ 。

神社境内には本社青島神社とは別に、摂社金刀比羅神社、捸 社稲荷神社も建てられた ${ }^{21)}$ 。1932 年の『神社協会雑誌』「青島神 社及忠魂碑の近況」には、「六月十四日青島稲荷神社地鎮祭執行、 十月四日青島稲荷神社上棟祭執行、十一月十四日鎮重祭執行」と 稲荷神社の創立過程が記録されている ${ }^{22}$ 。

本社青島神社の中には天照大神、明治天皇と国魂大神が奉祀 されていた ${ }^{21)}$ 。創建時の神社の宮司は遠山正雄で、春と秋の例祭、 歳旦祭、元始祭、成婚奉告祭、紀元節祭、明治天皇祭などが行わ れていた ${ }^{23)}$ 。「春と秋の例祭になると、青島全市から小学生（高 学年)、中学生、女学生が教師に引きつけられて何百人とあつま る。青島日本中学校の四年生と五年生、合計約二百人ほどは、三 十年式の銃を肩にし、銃剣をさげ、ゲートルを巻いて、集団参加 する。神社は宗教的というより軍隊的である」と戦争の時に青島

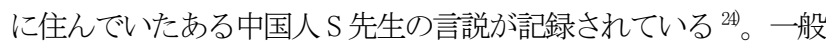
の日本人に対しては、神社が結婚やお産、病気平復祈願等の信仰 にも応えていたし、後述のように満開の桜が民衆に歓喜をもたら した。

青島神社は他の都市、満州国や日本国内の学校の見学団を多 く迎え入れていた。例えば、「昭和二年八月二十六日大谷大学鮮 満北支那見学団、十月二十日埼玉県教育視察団と満鉄教員北支那 見学団が青島神社を参拝した」と記されている ${ }^{25}$ 。青島神社の社 格は高く、影響力が強かったことがうかがえる。

\section{(2)青島神社の特徵}

青島神社は日本人関係の施設が集まっていた場所に立地してい た。参道の寸ぐ南側に高等女学校があり、女学校の「成績品」

(課題作品か)は神社の繪馬殿に陳列されたこともある22。

前述のとおり、1899 年からドイツ総督府がモルトケ山にも植 林していたため、日本が青島を占領した時には森林は相当成長し ていたと推定される。森林は日本の神社に不可欠な要素であると 考えられるから、これは若鶴山が選定されたもう一つの理由であ ると考える。

神社の入り口は若鶴二丁目（現遼寧路）に面する西側にあった。 参道は西から東に伸び、拝殿、本殿も西側に正面が向けられ、日 本の多くの神社が南側を正面としているのとは大きく異なってい る。だが、ソウルにある朝鮮神宮と台北にある台湾神社の配置図 26)を合わせてみると、植民地の神社の入り口が設置される際には 一定のルールがあったと考えられる。ソウルは日本の北西部にあ り、朝鮮神宮の入り口も北西部に設けられた。台北は日本の南西 部にあり、台湾神社の入り口も南西部に設けられた。青島の緯度 (北緯 36.06) は東京 (北緯 35.41) とほぼ同じであり、東京の西に位 置している (図-3)。そして、神社の入口も西側に設けられてい た。この三つの大規模な神社の入り口の方向を合わせて考えると、 おそらく日本人は自国への求心的な地理認識を有し、日本の方向 に向って神社に参拝するために、神社の入り口をそれぞれの方位 に設けたではないかと推測される。

神社の入り口から西へ真直に伸びている道路は「宮前町」(の ち神社町、現包头路）と名付けられた。道路の名前と位置を考える と、宮前町の中心の街路は青島神社の参道として計画された可能 性が高い。1948 年の雑誌『LIFE』に掲載された写真には神社町 の南側にある店の看板に「CAFÉ」と書かれている。写真の説明文 として「American named bars and restaurants lining the street（米国人がこの 道に沿うバーやレストランに名前を付けた)」という記述がある。お そらく日本時期には既に宮前町を中心として、コーヒーショップ、 レストランが多く立ち並ぶ、にぎやかな門前町ができていたと推 測される。

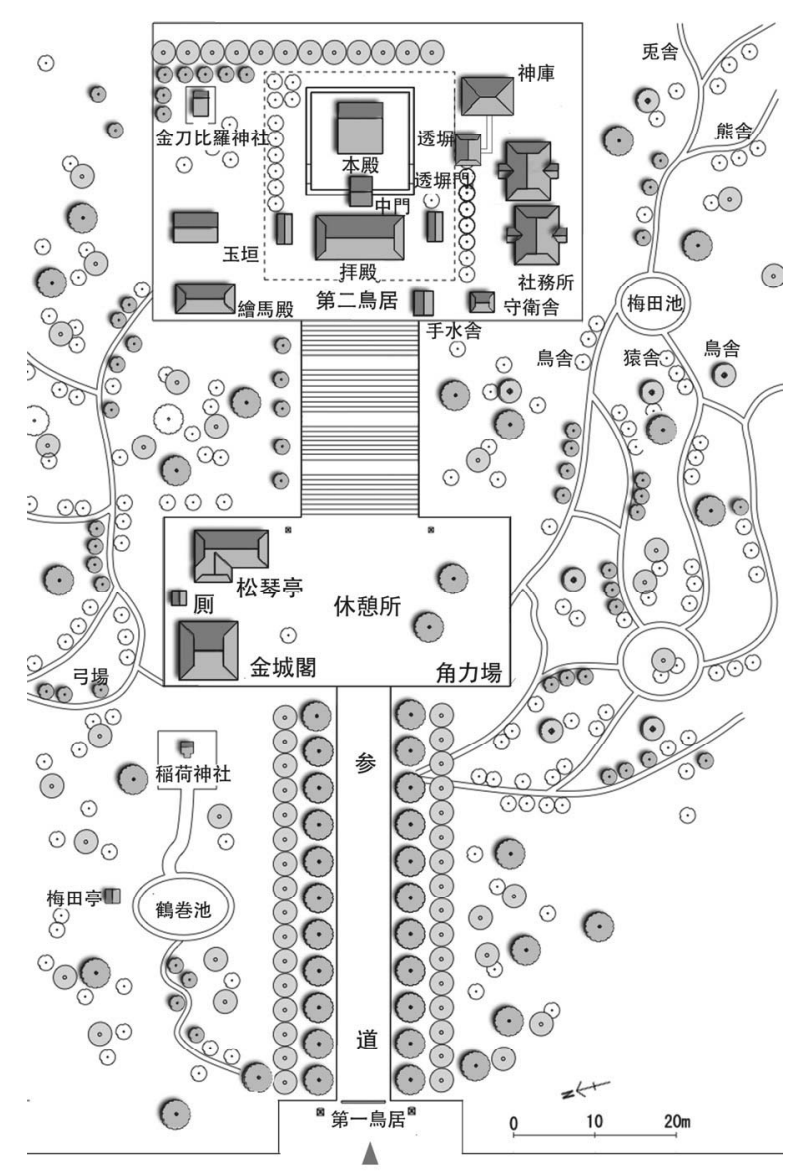

\section{図一3 青島神社の配置復原図 (『青島神社図絵』2)と「青島神社創立二関スル件申請」により作成)}

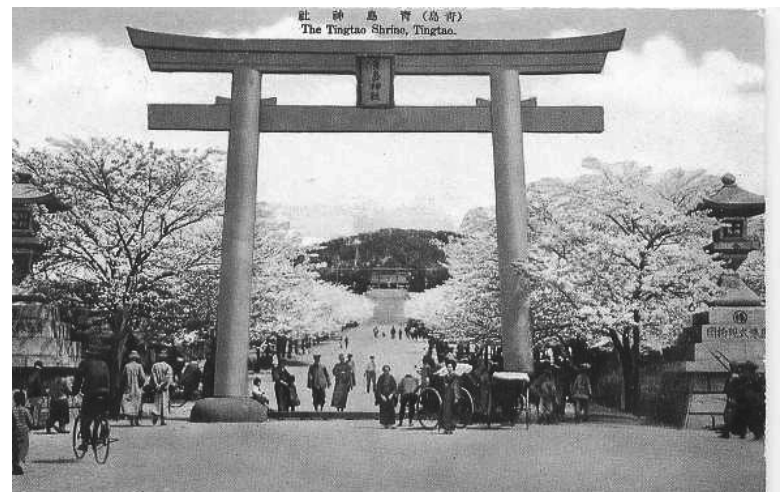

写真-1 参道両側の (http://qingdaopage. com/fi le/00811. html)

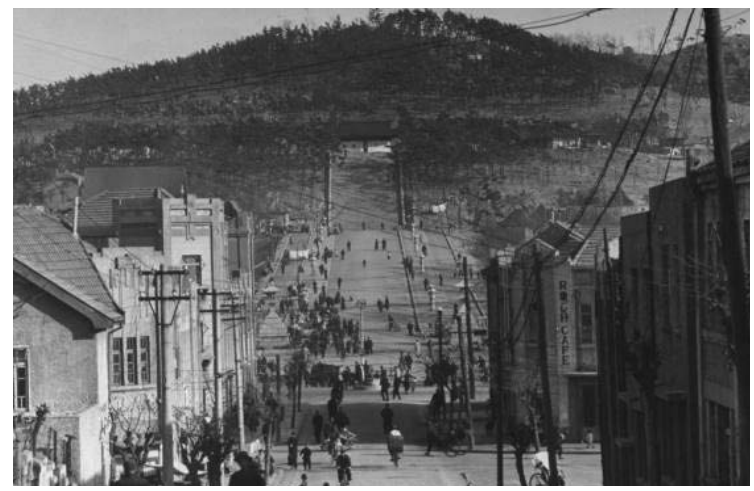

写真-2 包頭路と神社 ( 『IFE』雑誌写真档案から ${ }^{30}$ ) 
次いで、全体の構成については「神社は上下の二段となす。上 段は二千七百坪、下段は一千六百坪、両者と連絡する花崗石の階 段は幅員八間、百二十段である。建造物は本殿、中門、瑞垣、拝 殿、玉垣、仮神饌所、仮倉庫、神庫、第二鳥居、仮社務所、守衛 社、第一鳥居、手水社、社号標などがあった」とある ${ }^{20)}$ 。第一鳥 居から、本殿背後までまっすぐな軸線に貫かれており、これに沿 って上記の施設が左右に並心゙られていた。軸線の景観は山の高さ を利用し、神社の秩序、礼儀、尊峳の意味を強調した。図一3は 青島神社の復原図である。「青島神社創立二関スル件申請」に記 された計画段階のものと比べると、おおむ㱛実際に建設されてい たことが分かる。

日本は神社境内に自国の象徴とする桜を大規模に植えた。特 に注目すべきは、参道の両側に桜並木が対称に配置されていたこ とである (写真-1)。それに加え、1924 年 3 月には境内の女学 校上方一帯の境内林 6,000 余坪が開拓され、全て桜樹が植えられ た ${ }^{28}$ 。『神社協会雑誌』には「神苑植込桜樹高さ一丈内外のもの 二百十一本及高さ五尺以内の物（三年生、五年生）三千七百十七本 植込みを了せしが、大木二百余本の分は悉く開花参道並木の桜と 爛漫を競う。満開の前後に亘る一旬間は、団楽の家族、各種団体、 同家族会、各町内運動会等始め日本在住者の観桜催しは悉く境内 に集まりて甚盛なり）と桜満開の賑やかな情景が記録されている 28)。桜だけではなく、『青島神社眓絵』によると、松、ヒノキ、 梅等多くの種類の樹木が配置されており、季節により変化する豊 かな植物景観が形成されたと推測される。

また、境内には日本の伝統的な武術や遊興のための施設が数多 く建設された。「大正十三年四月十三日神社敷地下段南方に周囲 に並植、中に野天土間で、「鞍馬式」と呼ばれていた剣術道場が 設けられた」と記されている ${ }^{8)}$ 。そして、相撲場、弓場が神社に 造られたし、参道両側には池、亭、散歩道も設けられ、遊興の場 所が作り出された。また、神社境内の南側に兔舎、熊舎、鳥舎、 猿舎などが描かかれており、小さい動物園が形成された。こうし たら、神社は公衆の信仰と遊興の機能を兼ねていた。

詳細は不明だが、第一次日本時期には公園の整備計画がた てられていたものとみられ、「遊覧休養、娛楽、運動並びに市街 の記念装飾を主目的とな寸」緑地は普通公園として、「風景調和、 水源涵養」の森林は天然公園あるいは森林公園として位置づけら れていた ${ }^{20)}$ 。青島神社境内は公園の名前が与えられていなかった が、観賞樹木、運動する場所、動物舎などが設けられたため、 『土木誌』に普通公園として記録されている。したがって、この 時期には貯水山公園が成立したと考えられる。

(3) 支配の変遷に伴う貯水山の変容

1922 年には中華民国政府が日本政府から青島の主権を回復し た。農林事務所が日本時期の公園を基にして、青島市内の公園を 再整備、新規開設し、大小公園 19 ヶ所が形成された ${ }^{30}$ 。しかし、 日本人居留民は引き続き青島に滞在していた。そのため、日本人 の日常生活に必要な施設も日本の財産として保留されていた。
「山東懸案解決に関する条約」の第七条には「膠州ドイツの旧租 借地の公共財産の中の日本居留民団体の公益に欠くことのできな い学校、赦、墓地などは、日本の保留財産として居留民団が管 理する」と書かれている。附約によって、面積 56,695m²である青 島神社は日本居留民の公益地として保存された ${ }^{31)}$ (図一-4)。

1935 年 1 月には青島工務局は「青島市施行都市計画方案初 稿」(以下、「施行方案」) $)^{22}$ を編成した。「施行方案」の第八章の 「全市園林空地の計画」には「園林空地は水面など家屋、街路が ない、市民たちが遊興、休憩と運動する空間を提供する場所であ る。」と定義されている。これらは森林、公園、運動場、小運動 場、競馬場、ゴルフ場、水面、広場に細かく分けられて、面積

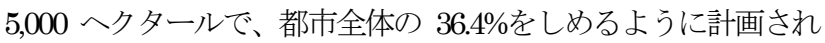
た。森林については「海抜が六十メートル以上の山地は森林保留 地に指定する」と規定されている。此の規定によれば、貯水山は 森林保留地になって、性格が変わらなかったものと推測される。 公園の計画については「市区内の公園が少ないので、現在の公園 は建築地にしてはならない。将来市区を拡大寸る時には、面積五 十へクタールの範囲内には必ず小公園一ヶ所を設ける」と述べて いる ${ }^{33)}$ 。

しかも、此の段階の計画によって、都市の範囲は日本時期より さらに北側に拡張され、シビック・センターが大港の東、貯水山 の北側に移され（図一5)、山は都市の中心緑地となり、その地位 が一層上がるはずであった。しかし、「施行方案」が未だ実施さ れていない段階で、中日戦争が勃発した。

1938 年に日本は再び青島を占領した。1941 年、日本政府は 「青島母市計画図」を公布したが、1947 年の市街地図と 1940 年 の市街地地図を比較すると、都市の建設はあまり進められていな かったことが分かる。青島神社は変わらずに 1945 年まで市街地 図に描かれている ${ }^{34}$ 。

1945 年の日本の敗戦後、中華民国政府は戦死者を供養するた めに、青島神社を忠烈祠として使用した ${ }^{350}$ 。1947 年の市街地図 によると、神社の場所には「忠烈祠」、隣には「中国公園」と書 かれている（図一6）。公園の名前を変えることによって、おそら く日本の景観と区別し、中国の尊篇を強調したかったためと考え られる。1948 年 12 月のアメリカ雑誌『LIFE』ほ3゙は青島の都市 景観、人々の生活などに関する特集写真 42 枚が掲げてある。そ の中には神社の写真が 2 枚含まれている。其の一枚は包頭路から とられた神社の写真である $(\text { 写真一 } 2)^{37)}$ 。この写真によると、第 一鳥居、第二鳥居、附属施設及び参道両側の樹木は既にとり除か れていたが、階段の上にある拝殿など重要な建物はまだ残されて いる。しかし、後述のように、1956 年には公園の道路、植生が 整理されたことから、神社の建物はその前にもうすべて撤去され たと判断される。

\section{4. 児童公園の成立と特徵}

（1）児童公園の成立

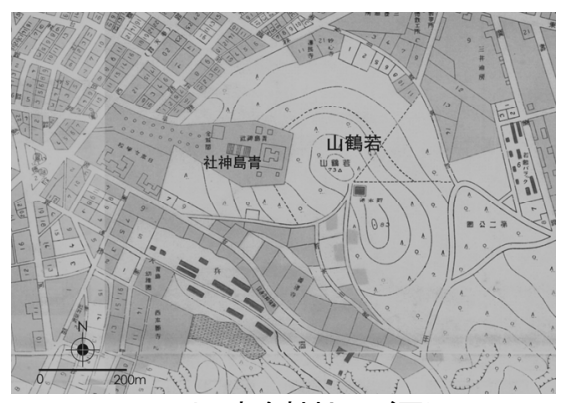

図一4 青島神社及び周辺

(1937 年の「最新青島市街一覧図」による)

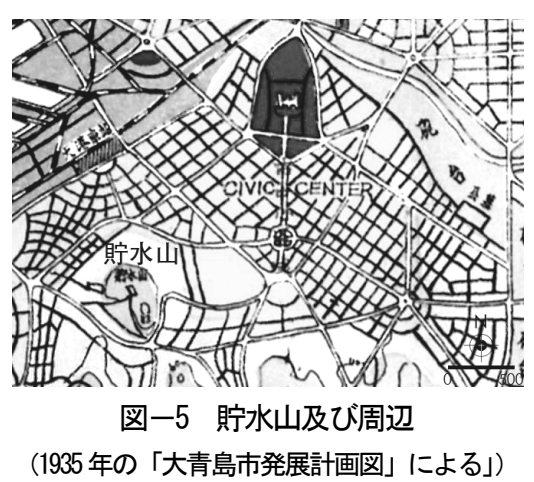

(1935 年の「大青島市発展計画図」による」)

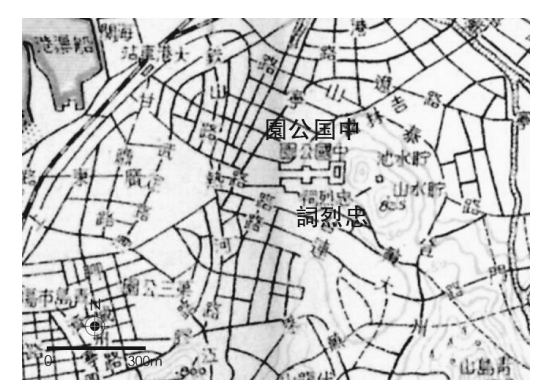

図一6 中国公園及び周辺

(1947 年の「青島市街道図」による) 
中華人民共和国が成立してからの青島市の公園の建設活動は、 回復（1951-1955 年)、建設（1956-1964年）、破壊（1966-1976 年）、 回復（1978-1982 年)、大規模建設（1984年-)の五段階に分けて理 解されている ${ }^{38)}$ 。1950-1951 年には続けて二回大規模な植樹活動 が行われ、市内の山が緑化されたが、貯水山もこの中に含まれて いた ${ }^{39}$ 。1956年には公園の主要道路が修築され、元参道の両側 にはヒマラヤスギが補植された。そして、山頂には黒松、アカシ ア、ハコヤナギが植えられ、山麓には池が整備され、池の側には 柳が植えられた。同年、公園の名称は「貯水山公園」に定められ た ${ }^{40)}$ 。

児童公園として建設が始まったのは 80 年代である。1982年に 青島市政府、婦人連合会が資金を寄せ集め、子供たちの娛楽施設、 十二支の動物の彫塑が設けられた ${ }^{411}$ 。1984年の「青島市全体都 市計画」には青島市の園林緑化について「海岸緑化に重点を置い て、山頂の風景を強調し、点、線、面を合わせ、(中略)、青島の 緑化系統を全体化させ」と目標が提出された ${ }^{42}$ 。同年 3 月 12 日

と 6 月 4 日には青島市政府が「山を閉鎖し、植樹・造園するお知 らせ」と「山頂公園十ヶ所 ${ }^{43}$ 㪰設するお知らせ」を出し、青 島の山々で植林し、公園を作る活動が始まった。

貯水山は山頂公園の一つとして植林されたほか、子供センター が建てられた。公園は「青島市児童公園」と命名された ${ }^{40)} 1986$ 年 7 月 6 日にはさらに「青島市貯水山児童公園」と改称されてい る ${ }^{4)}$ 。『青島市志』(園林緑化志)によると、80年代の青島市の 公園は総合公園、動物園、植物園、児童公園、記念公園と地区公 園に分けられており、貯水山公園は青島市唯一の监童公園として 記録され、また、現在でも唯一の児童公園のである位置づけは変 わっていない。

\section{（2）公園の特徵と神社の影響}

貯水山児童公園の施設や植物景観は中国風に改変されたが、青 島神社からのいろいろな影響が見られる。

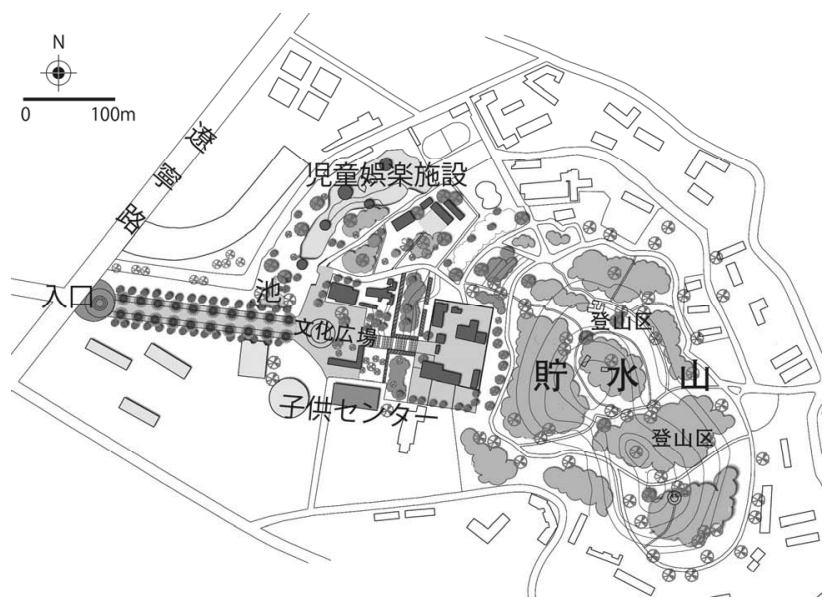

図-7 貯水山児童公園及び周辺 （公園の案内図と航空写真により作成）

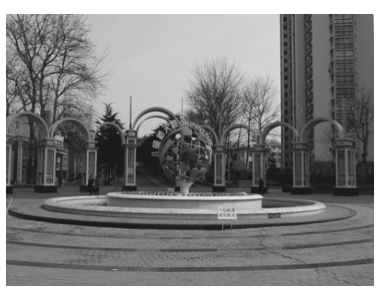

写真-3 公園の入口 (筆者撮影)

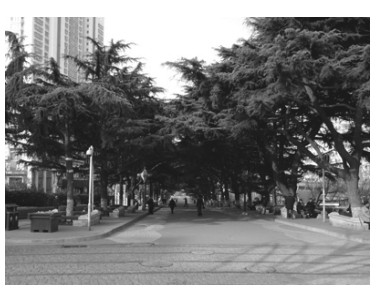

写真-4 参道に植えられた ヒマラヤスギ (筆者撮影)
まず、貯水山公園は遼寧路（日本時代の若鶴町）の東、貯水山に 立地しており、公園の入り口は神社当時のまま西に設置されてい る。ただ、第一鳥居の位置には現在、広場、噴水と彫刻、アーチ の門が立っており、現代公園の雰囲気を示している（写真一 3$)$ 。 次に、貯水山公園は入り口から、山腹にある階段までまっすぐの 軸線を持っており、記念的な景観の特徵が強く感じられる。これ は神社の空間構成からの影響である。また、前述のように、桜並 木は神社の一部とみなされ、1948年頃既に伐採されていた。桜 の代わりに、1956年に、道路の両側にヒマラヤスギが植えられ た (写真一4)。ヒマラヤスギは松科に属し、寿命が長くて寒さに 耐えられる特徵を持っている。松は昔から中国人に特に詩人や画 家に愛され、徐々に「強勒「「節操」の文化的象徵になった。現 在、中国の陵墓などの記念景観には松が多く使われている。貯水 山公園の桜がヒマラヤスギに替えられたのは日本の文化的象徵を 中国の文化的象徵に変える意図があったと推測される。

軸線の北側にある池の位置は、神社の鶴巻池の位置と大体一 致し、それは神社の池をもとに整備されたと考えられる。池のそ ばに中国風の亭、栈道が設けられ、中国古典庭園の要素が加えら れた。元参道の南側にあった公園、動物園も建て替えられ、子供 センターが建設されている（図一7）。一方、貯水山の西側には P.C.モール、レストラン、アパートなど新たな商業施設が多く立 地している。宮前町を中心としてできた神社の門前町の商業街的 性格は変わっていないが、新たな建物の高さは山の高さを超えて おり、神社が元来持っていた神聖感は著しく減じられた。

現在、貯水山公園は市民に開放され、都市の重要な公共空間 として使われている。毎日市民たち、特にお年寄りの方々がここ で散歩したり、ダンスをしたりして、のんびりと過ごしている。 また、毎年の正月にここで一週間の大根祭りが行われており、貯 水山公園は新しい形式で青島市民の生活に適合している。

\section{5. おわりに}

以上のように貯水山ではドイツ、日本、中国三国の文化の影 響を受けつつ、現代都市公園が形成されてきた。その中では日本 の影響が最も強かったと考えられる。前述のように、日本時期の 都市計画によって、貯水山の周辺には商業、工業、住居など様々 な施設が集まって、ドイツ時期の郊外地から市街の中心になった。 そして、日本の文化では山が神聖な場所と見なされるため、貯水 山は青島神社の鎮座地として選定された。その後 1945 年までの 間には青島神社はずっと日本人に管理され続けた。このように長 い時間存在した青島神社は現在の公園の立地、入口、構成に大き な影響を与えた。一方、中国人にとって神社は中国の寺廟と似て いるから、青島神社が「日本大廟」と呼ばれ、山も「大廟山」の 名称を与えられた。神社はその後取り除かれたが、「大廟山」と いう名称は現在まで通称として用いられている。青島神社の影響 が強すぎて、ドイツの文化の影響はほとんど見られなくなった。 ただ、初期に水源の役割を果たしたと言う事実は現在でも貯水山 という名前にその名残りをとどめている。

新中国が誕生して以後、緑地の機能が重視され、何度も再整 備されて、現在の貯水山公園が形成された。入り口の彫刻、古典 風の庭園、参道両側のヒマラヤスギなどの施設と植物景観で中国 の文化が強く示されている。しかし、象徴的な施設は撤去された ものの、空間構成から神社の面影が見られるし、山頂の緑化の基 調樹種であるニセアカシアとクロマツも認められ、公園には三国 の文化が映っている。

\section{補注及び引用文献 :}

1）青島市人民政府 :「青島市都市全体計画（1995-2010)」，15pp

2）公園の名称は時期によって変化するが，以下「貯水山公園」で統一寸 
る。ただし，改称があったことは文中に明示する。

3）青島市档案館（2007）：『膠奥発展備忘録』全訳, 中国档案館出版社. 『膠州湾発展備忘録』はドイツ青島総督府が作成した政府の業務報告で ある。1 898 年 10 月から出版され，1910 年に『膠奥年鑒』に変更され， 青島の 17 年の歴史を記録した。

4) 田久江南 (1921): 『青島要覧』, 新極東社発行

5）欧受大日記』は陸軍大臣官房が編集して保存した陸軍省大日記の一連 の文書の一部である。青島に関する欧受大日記は青島守備軍が発簡また は接収した文書が編まれた薄册である。その中に, 皇室, 外交, 礼儀, 教育, 編制, 軍需, 作戦, 婚姻, 葬祭などに関する書類が収められてい る。本論文ではアジア歴史資料センターのホームページ (http://ww. jacar. go. jp/) 上に提供されている史料を主として使用した。 6）趙琪修・袁荣（1928）: 『膠奥志』, 成文出版社，121pp。『膠奥志』は青 島の沿革，範囲，民社，政治，食物，交通，教育，建置，財税，人物， 芸文，大事の全 12 巻にわたり，青島の歴史を記録している。

7）中・日の研究者徐飛鹏・村松伸らが著した『中国近代建築総覧-青島 篇』が青島における近代建築の位置，機能，設計者と竣工の日付を記録 している。ドイツ研究者ワーナーの『中国におけるドイツ建築』 (Torsten Warner, DEUILSCIE ARITEKUTRR IN AHINA Architekuturturansfer, Ernst \&Sohon, 1994）の中に青島においてドイツ時期に建設された建築に ついての記述がある。近年，青島建築に関する修士論文が多く出てきた。 例えば, 華僑大学の陳霹「近代青島建築研究」(2007)。南京林業大学の 王福雲「青島近代別荘建築及ひ環境芸術研究」(2007.6)。青島理工大学 の徐強「青島近代教会建築の特徵」（2010.6）が青島各種類の建築を研 究している。

8）青島の都市計画に関する研究は武漢理工大学李百浩研究室が行ってお り，李彩の修士論文「青島近代都市計計画歴史研究」(2005.5）が青島 の都市計画を三期に分けて論じている。ドイツのワーナーの『近代青島 の都市計画と建設』(東南大学出版社, 2011) がドイツ時期の都市計画 と建設を研究している。

9）鄭愛芬（2010）「「青島市公園緑地木質植物の多様性」，南京林業大学修 土論文

10）前掲 3)，13pp

11）前掲 3)，55pp

12）前掲 3)，81pp

13）前掲 3), 108pp

14）青島市史志事務室・林業局・都市園林局（2007）:『青島古樹名目 志』, 中国海洋大学出版社, 66pp

15) Jork Artelt (2011.5) : Tsingtau, Deutsche Stadt und Festung in China 1897-1914. 青島档案館訳, 『青島都市之軍事要塞建設研究 (1897-1914)』,

青島出版社，65.140pp には 1907 年のモルトケ山とビスマーク山の防御施 設平面図が掲載されている。1913 年の青島市街地図にモルトケ兵営が描 かれている。

16）前掲 3)，532pp

17）ワーナー (2011)：『近代青島における都市計画と建設』，73pp に転載 されている。

18）青島守備軍大正四年度第一統計年報，第三人口

19）「外務省記録」の「山東占領地処分一件別冊 $/$ 細目協定関係 /公有財 産問題参考資料一／青島市街工事計画」に付図「青島市街図」が掲載さ れている。「外務省記録」は明治初期の外務省創立以来第二次大戦終了 までの約 80 年間の在外公館との往復電報・公信類をはじめとする外交 活動にともなう史料であり，前述のアジア歴史資料センターで提供され ている (http://ww. jacar. go. jp/DAS/meta/MetaOutServlet)。

20）神社協会（1919）：『神社協会雑誌』，第十八年，第十二号，33pp。『神 社協会雑誌』は神社協会が 1902 年に創刊, 1938 年に終刊した神社研究 に関する雑誌である。その中の「各地通信欄」には日本が海外で建設し た神社も掲載されている。

21）青島守備軍 : 『欧受大日記』第五二七号，「青島神社創立に関する件申
請」

22）前掲 20）（1932），第三十一年，第二号，64pp。なお，金刀比羅神社の 創立過程は記述されていない。

23）前掲 20）（1924：第二十三年，第六号，72pp

24）日高六郎 (2005.6) : 『戦争の中で考えたこと一ある家族の物語』, 筑摩 書房, $107 \mathrm{pp}$

25）前掲 20）（1927）:第二十六年，第十二号，78pp

26）青井哲人（2005.2）:『植民地神社と帝国日本』，吉川弘文出版社，147159

27) 辻子実 (2007.2)：『侵略神社』, 新幹社, 103pp

28）前掲 23), 72pp

29）青島守備軍民政部土木部（大正九年五月）:『土木誌』，56-57

30） 1922 年中日「山東䀣案解決に関する条約」及び附約が『膠奥志』「沿 革志」「中国回復の顛末」に掲げられている。その第七条には日本保留 財産が規定されていた。(甲) 日本領事館に必要な財産と（乙）日本人 居留民団に必要な財産に分けられている。乙は日本人会, 化学試験所, 青島病院, 中学校, 高等女学校, 第一小学校, 青島神社, 忠魂碑, 青島 斎場，火葬場，墓地を含んでいる。

31）前掲 6), 122pp

32）青島工務局（1935. 1)：「青島市施行都市計画方案初稿」。この中で序 言, 計画の範囲, 都市発展の推測, 計画の原則, 中心部の計画, 街路, 公園システム, 交通, 衛生, 土地整理, 実施について詳細に論じてい る。

33）前掲 32）,37pp

34）折下吉延は青島特別市の都市計画の仕事を委嘱され，1940 年に青島に 移った（都市計画協会（1967）:『折下吉延先生業績録』，126pp。1941 年 には折下が青島市青島神社境内を設計した (佐藤 昌 (1977) :『日本公 園緑地発達史』(下巻), 都市計画研究所, 391pp)。しかし, 戦争があっ たため，実施されたどうか不明である。

35）青島市档案館（2010.8）:『青島通鑒』，中国文史出版社，157pp

36）【LIFE』雑誌は 1936 年に発刊されたアメリカの雑誌である。2007 年か ら内容は google に移された (http://images. google. com/hosted/1ife/7fcf6e591cfe6816. html)。

37）二枚の写真のうち一枚は論文の中に掲げられており，もう一枚の写真 はアメリカの兵士と神社の灯籠を写している。

38）青島市志事務室（1997.8）:『青島市志』(園林緑化志), 新華出版社, $79 \mathrm{pp}$

39）前掲 38）, 6pp

40）青島市志事務室（1997.8）:『青島市志』(旅行志)，新華出版社，39pp

41）前掲 38), 24pp

42）前掲 40)，71pp

43）山頂公園十ヶ所は観海山，観象山，信号山，青島山，太平山，貯水 山，嘉定山，北嶺山，楼山，烟敦山である。

44）青島市園林政務ホームページhttp://www.qdyuanlin.gov.en/news 